\title{
Helium and neon isotopes in São Miguel island basalts, Azores Archipelago: New constraints on the "low ${ }^{3} \mathrm{He}$ " hotspot origin
}

\author{
Manuel Moreira $^{\mathrm{a}, *}$, Aisha Kanzari a, Pedro Madureira ${ }^{\mathrm{b}, \mathrm{c}}$ \\ a Institut de Physique du Globe de Paris, Sorbonne Paris Cité, CNRS (UMR 7154), 1 rue Jussieu, 75238 Paris Cedex, France \\ b Centro de Geofísica de Évora/Dep. Geociências U. Évora, R. Romão Ramalho, 59, 7000 Évora, Portugal \\ c Estrutura de Missão p/ Assuntos do Mar, R. Costa Pinto, 165, 2770-047 Paço de Arcos, Portugal
}

\section{A R T I C L E I N F O}

\section{Article history:}

Received 24 October 2011

Received in revised form 20 April 2012

Accepted 24 June 2012

Available online 2 July 2012

Editor: L. Reisberg

\section{Keywords:}

Azores

Helium

São Miguel island

Isotopes

Underplating

\begin{abstract}
A B S T R A C T
Lavas from the São Miguel Island, Azores Archipelago, have peculiar isotopic compositions, including radiogenic lead and strontium and un-radiogenic neodymium. The peculiar isotopic trend of São Miguel is evident in the lead-lead diagram where both ${ }^{207} \mathrm{~Pb} /{ }^{204} \mathrm{~Pb}$ and ${ }^{208} \mathrm{~Pb} /{ }^{204} \mathrm{~Pb}$ ratios are high for a given ${ }^{206} \mathrm{~Pb} /{ }^{204} \mathrm{~Pb}$ ratio compared to other oceanic island basalts. This signature is unique among OIBs and is particularly evident in the Nordeste area, the oldest part of São Miguel island ( $\geq 1 \mathrm{Ma}$ ). Only a few olivine samples from the Nordeste volcanic complex have been analyzed for helium. They show radiogenic helium signatures with ${ }^{4} \mathrm{He} /{ }^{3} \mathrm{He}$ up to 174,000 (R/Ra 4) [Moreira et al., Helium and lead isotope geochemistry in the Azores archipelago, Earth Planet. Sci. Lett. 169: 189-205, 1999]. However, because the Nordeste volcano has an age between 1 and $4 \mathrm{Ma}$ and because these samples have low helium concentrations, these radiogenic helium isotopic ratios must be considered with caution as they can also reflect post eruptive radiogenic production. In this paper we present a detailed study of the helium and neon isotopic ratios obtained from 17 Nordeste samples in order to better constrain the helium isotopic signature of the São Miguel mantle source. By coupling helium and the other isotopic systems, we propose that the São Miguel source contains non-degassed material, enriched in $U$ and Th, that was stored in the mantle for the last $\sim 3 \mathrm{Ga}$. As suggested by Elliot et al. [Elliott et al., The origin of enriched mantle beneath São Miguel, Azores, Geochim. Cosmochim. Acta 71: 219-240, 2007], underplated magma intruded into oceanic lithosphere and subducted $\sim 3$ Ga ago is a possible explanation for the peculiar São Miguel source isotopic signatures.
\end{abstract}

(c) 2012 Elsevier B.V. All rights reserved.

\section{Introduction}

Helium isotopes have been used extensively to constrain mantle structure and evolution. The rare isotope ${ }^{3} \mathrm{He}$ is considered to be dominantly primordial whereas ${ }^{4} \mathrm{He}$ is the radiogenic product of $\mathrm{U}$ and Th radioactive decay chains. Many oceanic island basalts (OIB) exhibit a "primitive" helium signature. This is shown by their low ${ }^{4} \mathrm{He} /{ }^{3} \mathrm{He}$ isotopic ratios (down to 18,000 or $\mathrm{R} / \mathrm{Ra}=50$ where $\mathrm{R}$ is the ${ }^{3} \mathrm{He} /{ }^{4} \mathrm{He}$ ratio and $\mathrm{Ra}$ the same isotopic ratio in the atmosphere) Hilton et al., 1999; Stuart et al., 2003), significantly lower than the mean MORB ratio $\left({ }^{4} \mathrm{He} /{ }^{3} \mathrm{He} \sim 90,000 \pm 10,000\right.$ or $\mathrm{R} / \mathrm{Ra} \sim 8 \pm 1$, Allègre et al., 1995). These low ${ }^{4} \mathrm{He} /{ }^{3} \mathrm{He}$ ratios in OIB reflect mantle sources having low $(\mathrm{U}+\mathrm{Th}) /{ }^{3} \mathrm{He}$ ratios. This is interpreted as enrichment in ${ }^{3} \mathrm{He}$ in OIB sources in order to preserve low $(\mathrm{U}+\mathrm{Th}) /{ }^{3} \mathrm{He}$ ratios since these are also enriched in trace elements (including $U$ and $T h$ ) compared to the MORB source. The MORB source contains less ${ }^{3} \mathrm{He}$

\footnotetext{
* Corresponding author.

E-mail address: moreira@ipgp.fr (M. Moreira).
}

because it was degassed in early Earth history (Staudacher and Allègre, 1982; Allègre et al., 1986). However, some OIBs present higher than MORB ${ }^{4} \mathrm{He} /{ }^{3} \mathrm{He}$ ratios. This is the case of St Helena, Gough, Tristan da Cunha, Ascension, Comores, Marquesas, Canaries, Raivavae and Heard islands (Graham et al., 1993; Hilton et al., 1995; Hanyu and Kaneoka, 1997; Hilton et al., 2000; Class et al., 2005; Ammon et al., 2009; Parai et al., 2009). The interpretation of such high ratios is more complicated than for "primitive" hotspots since high ratios can reflect mantle (recycled) components or shallow processes such as magma chamber degassing, followed by in-situ radiogenic production or crustal contamination (Zindler and Hart, 1986: Hilton et al., 1995; Class et al., 2005). Understanding the origin of these "low ${ }^{3} \mathrm{He}$ " hotspots is fundamental to constrain the nature of the recycled material in the mantle.

An example of an oceanic island having radiogenic helium is São Miguel Island in the Azores archipelago (Fig. 1) (Kurz et al., 1990; Kurz, 1991; Moreira et al., 1999). In this paper, we present new helium and neon isotope data from samples collected on an extinct volcanic complex (Nordeste) in the eastern part of São Miguel that present the most radiogenic lead and strontium, in order to constrain the origin of the "low ${ }^{3} \mathrm{He}$ " hotspots. 